\title{
Growing Speed of Cumulonimbus Turrets
}

\author{
Fumiaki Kobayashi ${ }^{1}$, Akihito Katsura ${ }^{1}$, Yoichi Saito ${ }^{2}$, Tamio Takamura ${ }^{2}$, \\ Toshiaki Takano ${ }^{3}$, and Daisuke Abe ${ }^{4}$ \\ ${ }^{1}$ Department of Geoscience, National Defense Academy, Yokosuka, 239-8686, Japan \\ ${ }^{2}$ Center for Environmental Remote Sensing, Chiba University, Chiba, 263-8522, Japan \\ ${ }^{3}$ Graduate School of Engineering, Chiba University, Chiba, 263-8522, Japan \\ ${ }^{4}$ Weathernews, Chiba, 261-0023, Japan
}

\begin{abstract}
On the basis of simultaneous observations of cumulonimbi using the millimeter-wave radar, the X-band radar, and photogrammetry, initiations of isolated cumulonimbi in the Kanto region of Japan were presented. These cumulonimbi were organized by the continuous generation of turrets. The growth speeds of turrets were quite different among the life cycle of the cumulonimbus. The values of the growth rates increased through the life cycle of cumulonimbus in the cases of the multi-turret, and varied from $2 \mathrm{~m} / \mathrm{s}$ to $13 \mathrm{~m} / \mathrm{s}$. The time relationship between the generation of cumulonimbus clouds and the turret development is different among the cases analyzed in the study. The turret developed forty minutes after the cloud generation in the case of 23 August 2010.
\end{abstract}

Key words : cumulonimbus turret, convection initiation, X-band Doppler radar, cloud radar

\section{Introduction}

The understanding of the cumulonimbus $(\mathrm{Cb})$ generation process and the fine structure of $\mathrm{Cb}$ is of great importance not only for scientific purpose, but also for the mitigation of heavy rainfall disasters and high winds. Heavy rainfall often occurs in the Tokyo Major Metropolitan Area during the afternoons on fine mid-summer days. For example, a heavy rainfall event, of which hourly rate was $131 \mathrm{~mm}$, occurred in Nerima on 21 July 1999 (Kobayashi et al. 2001; Seko et al. 2007). Furthermore, the relationship between cumulus convection and heat islands is one of the most important issues with implications on urban climate. The generation or development of cumulus $(\mathrm{Cu}) / \mathrm{Cb}$ in urban areas has been extensively discussed (e.g., Changnon 1981; Fujibe 1998; Saito and Kimura 1998; Sato and Takahashi 1999; Fujibe et al. 2002; Inoue and Kimura 2004; Kobayashi et al. 2007). In order to clarify these problems, it is necessary to observe the fine structure of the Cb initiation and the contiguous development.

Kobayashi et al. (2003) and Kobayashi (2009) investigated the spatial distribution of first radar echoes (first echoes) in southern Kanto region in mid-summer days. Many of the first echoes were generated over the Boso Peninsula and the foot of the Tanzawa mountains during the early afternoon; some were also generated over the plains of southern Kanto, and 
over the metropolitan area during the afternoon. Approximately $50 \%$ of first echoes are generated over the mountain regions in the Boso Peninsula and around the Tanzawa in the early afternoon, as well as $15 \%$ in the metropolitan area. The highest frequency area of first echoes was found in the north and northwest parts of the metropolitan area. The first echoes were most actively generated between 11:00 and 17:00 JST. Most first echoes were generated at $1.5 \mathrm{~km}$ AGL (above ground level) over mountain regions and at much higher altitudes (above $3 \mathrm{~km}$ ) over the metropolitan area.

The Cb cloud turrets, which are bulbous $\mathrm{Cb}$ inner structures with a horizontal scale of 1 to $3 \mathrm{~km}$ and representing the overturning air, are developed continuously (Fig. 1). The tufts of $\mathrm{Cb}$ are the smallest unit of $\mathrm{Cb}$ with a horizontal scale of approximately $100 \mathrm{~m}$. The structure and developing process of turrets and tufts remain uncertain because of the lack of observational data. As weather radars (C-band or X-band) are operated at a beam width of $1^{\circ}$, a tangential resolution is approximately $500 \mathrm{~m}$ at $30 \mathrm{~km}$ apart from the radar. In order to observe the fine structure of turrets, it is necessary to use the high-resolution radar.

Kobayashi et al. (2011) successfully detected the generation of turrets using the $95-\mathrm{GHz}$ FM-CW cloud radar. Simultaneous observations of Cbs using the $95-\mathrm{GHz}$ cloud radar, the $\mathrm{X}$-band radar, and photogrammetry were carried out during the summer of 2010 in the Kanto region, Japan. They showed the developing process of an isolated Cb above the cloud radar site on 24 July 2010. A continuous generation of turrets was observed and a total of four turrets formed. The cloud radar detected echoes approximately two minutes after the generation of the turret. The intermittent echo pattern observed by the cloud radar denotes fine structures in the $\mathrm{Cb}$.

The purpose of this study is to make clear the fine structure of Cb turrets using the $95-\mathrm{GHz}$ cloud radar, the X-band Doppler radar, video cameras and the MTSAT-1R rapid scan data. This paper presents the growth speeds of the turrets observed both in summer of 2010 and 2011 in the Kanto region and describes the temporal and spatial relationships between the cloud development and the radar echoes obtained by both radars.

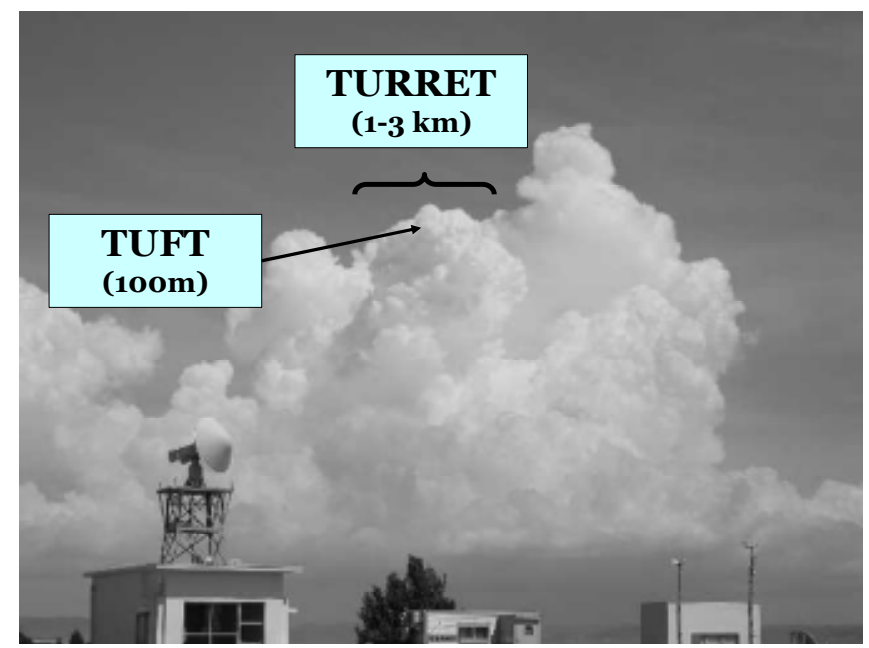

Fig. 1. A photo of a cumulonimbus observed from the Yokosuka radar site. 


\section{Observation methods}

An X-band Doppler radar was installed at the National Defense Academy (NDA) of Yokosuka (100 $\mathrm{m}$ above sea level) to observe the $\mathrm{Cb}$ development around the metropolitan area. The Doppler radar was operated at $9.7 \mathrm{GHz}$ with a wavelength of $3 \mathrm{~cm}$, a beam width of $1^{\circ}$, a minimum detection reflectivity signal of $16 \mathrm{dBZ}$, a radial resolution of $125 \mathrm{~m}$, a Nyquist velocity of $16 \mathrm{~m} / \mathrm{s}$, and an antenna scan rate of $6 \mathrm{rpm}$. The plan position indicator (PPI) volume scan with a 14 -step (from 0.5 to $19.5^{\circ}$ ) mode observation was conducted at 5 -minute intervals. The NDA radar had a radial maximum range of $64 \mathrm{~km}$. This range also covered the Chiba radar site (Fig. 2). Daytime cloud images were captured by time-lapse video and still photography during periods of $\mathrm{Cb}$ development.

A 95- GHz frequency-modulated continuous wave (FM-CW) cloud radar named FALCON-I (Takano et al. 2008) was installed at Chiba University (Chiba site) to fully understand the fine structure of various clouds. This cloud radar is a vertically pointing radar, producing Doppler measurements. It was operated at $95 \mathrm{GHz}$, and had a beam width of $0.2^{\circ}$, a sensitivity of reflectivity signal of $-32 \mathrm{dBZ}$ at $5 \mathrm{~km}$ apart from the radar, a radial resolution of $15 \mathrm{~m}$, and a Nyquist velocity of $3.2 \mathrm{~m} / \mathrm{s}$. The distance between the Yokosuka and Chiba sites is $52 \mathrm{~km}$ and, the latter site is located at a direction of 39 degree North of the former (Fig. 2).

Simultaneous observations using the $\mathrm{X}$-band radar and the cloud radar have been conducted during two summer months in 2010 and 2011. Isolated Cb turrets generated in the afternoon on a fine mid-summer day were observed on 24 July 2010 (Case II), 23 August 2010 (Case I) and 7 August 2011 (Case III). The height of each turret was estimated geometrically using the following methods in this study; a theodolite observation of the turret top (Case III), a stereo-photographing method (Case II, Kobayashi et al. 2011) and analysis of video image (Case I). The observational errors were estimated on the order of $10 \mathrm{~m}$ (theodolite) and $100 \mathrm{~m}$ (stereo analysis and image analysis), respectively. This spatial resolution is sufficient for the discussion of the cloud height on the order of $1 \mathrm{~km}$.

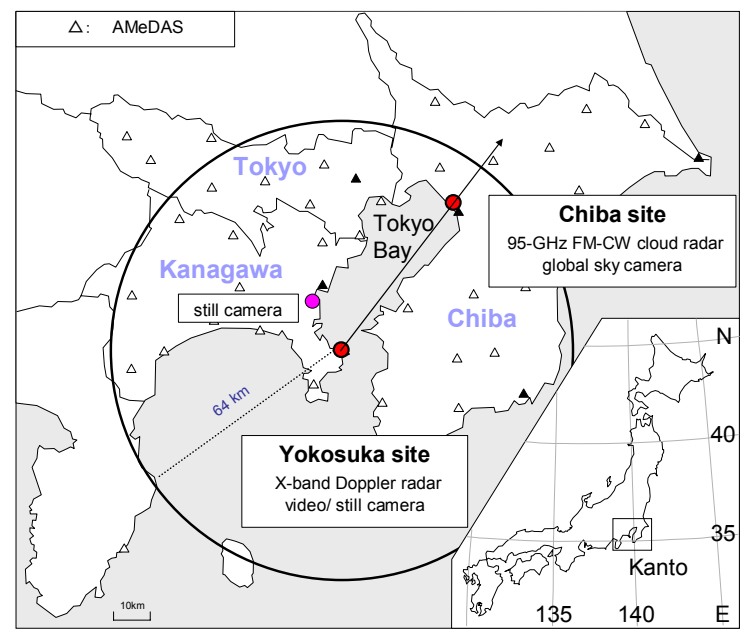

Fig. 2. The locations of the observation sites (solid circles). The large circle shows the NDA radar range $(64 \mathrm{~km})$. Solid and open triangles denote meteorological observatories and AMeDAS stations of JMA, respectively. 


\section{Observational results and discussion}

\subsection{Case I : Multi-turret on 23 August 2010}

According to the weather chart of 09 JST 23 August 2010, a pressure of 1016-hPa Pacific high over east Japan meant it was a clear sky day over the Kanto region. By noon, the temperature in Tokyo and Chiba had exceeded $30{ }^{\circ} \mathrm{C}$ at Ootemachi and Chiba AMeDAS (Automated Meteorological Data Acquisition System) stations, and the maximum temperature exceeded $35^{\circ} \mathrm{C}$ (very hot day). Figure 3 (a) shows sounding curves at Tateno that were released four hours before the generation of the $\mathrm{Cb}$ and $60 \mathrm{~km}$ away from the $\mathrm{Cb}$ generation point. The sounding suggests conditions were similar to those of $\mathrm{Cb}$ generation over the Kanto region in the mid-summer days. The inversion layer existed between 800 and $700 \mathrm{hPa}$ and a relatively high humidity layer existed below $800 \mathrm{hPa}$. Above this level, the convective instability layer developed up to $150 \mathrm{hPa}$. The thermodynamic parameter of CAPE (convective available potential energy) and CIN (convective inhibitation) was 2100 and $30 \mathrm{~J} / \mathrm{kg}$, respectively. The large number of CAPE and small value of CIN close to zero suggest the active of thermal convection. The level of tropopause was assumed approximately $14 \mathrm{~km}(150 \mathrm{hPa})$ on the day. In addition, the wind speed was weak up to $500 \mathrm{hPa}$ under the Pacific high. No radar echo was observed in the X-band radar range until 13:30 JST on the same day.

On the basis of satellite data, many of $\mathrm{Cu}$ clouds were generated and ranged over the central area of the Boso Peninsula in the afternoon (Fig. 3 (b)). An isolated Cb developed suddenly near the Chiba site after 13:30 JST. Except for the Cb that was generated and developed around Chiba, there were no other $\mathrm{Cb}$ clouds or no echoes over the Kanto plain at the time (Fig. 4). First echoes, as defined by Kobayashi and Inatomi (2003), are thundercloud echoes which are traced back to the emerging echoes or initial convective echoes observed by the X-band radar at reflectivity greater than $16 \mathrm{dBZ}$. At 13:42 JST, the first echo appeared at a height of $4 \mathrm{~km}$ AGL in the case. After that, the echo developed gradually, having an echo core region of $40 \mathrm{dBZ}$ until 14:10 JST.
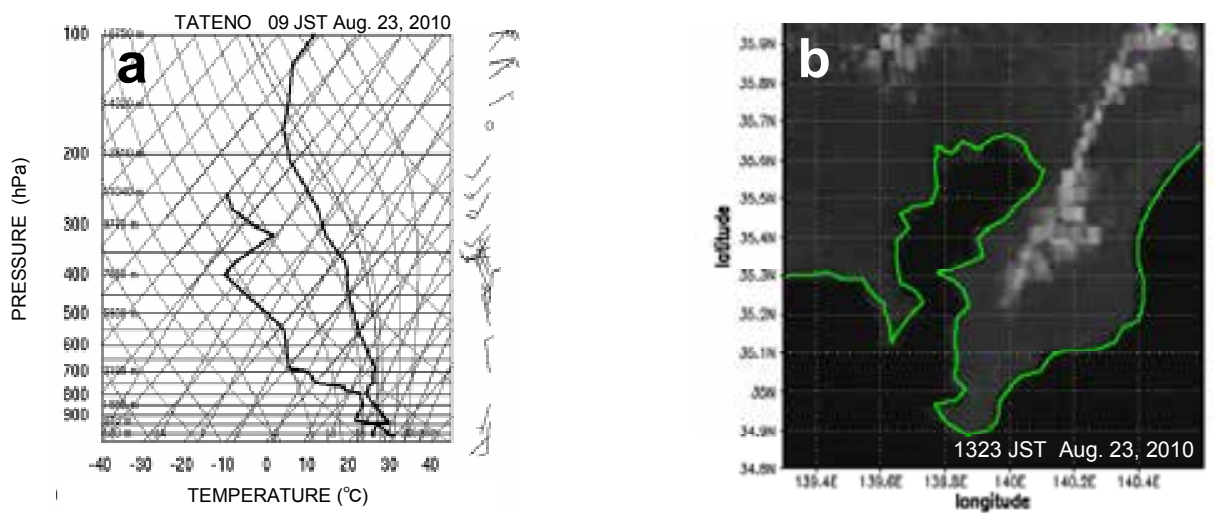

Fig. 3. (a) Vertical profiles of temperature, dew-point temperature and wind (full barb is $5 \mathrm{~m} / \mathrm{s}$ ) at Tateno at 09 JST 23 August 2010. (b) Visible image of the MTSAT-1R rapid scan at 13:23 JST. 


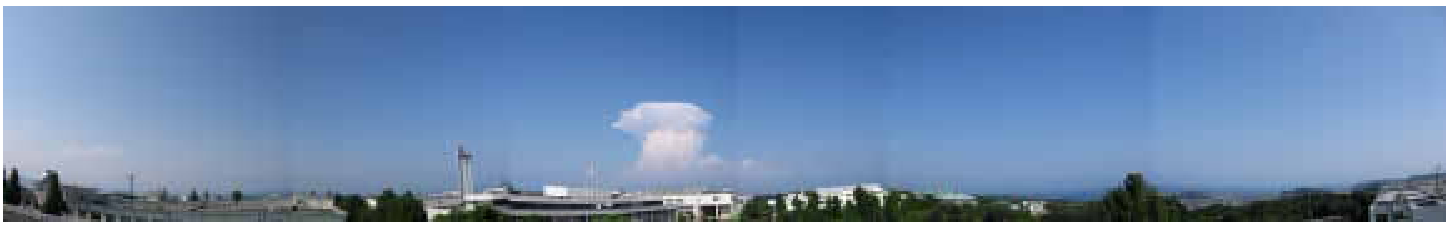

Fig. 4. A photo of an isolated cumulonimbus at 14:40 JST on 23 August 2010, observed from the Yokosuka site.

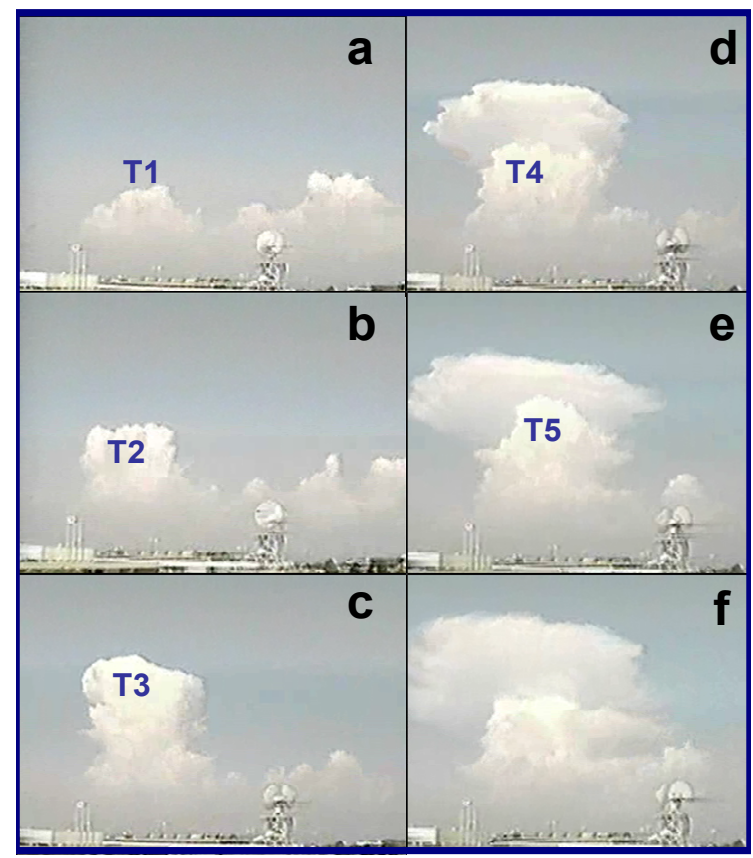

Fig. 5. Video still images on 23 August 2010. (a) 14:12 JST. (b) 14:22. (c) 14:32. (d) 14:42. (e) 14:52. (f) $15: 12$.
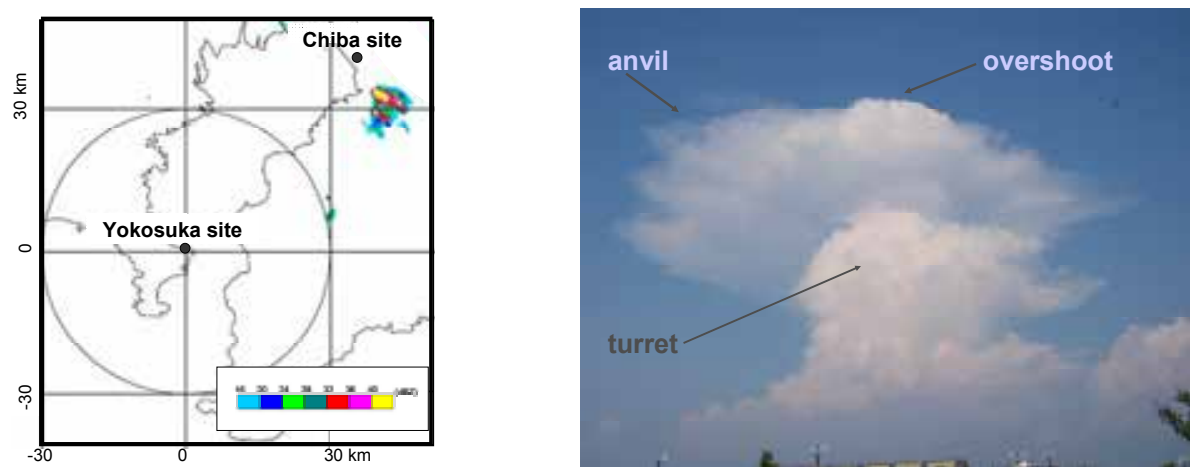

Fig. 6. X-band radar echo pattern of PPI $\left(\mathrm{EL}=4.8^{\circ}\right)$ on 23 August 2010 at 14:22 JST (left). A photo of the cumulonimbus at 14:58 JST (right). 


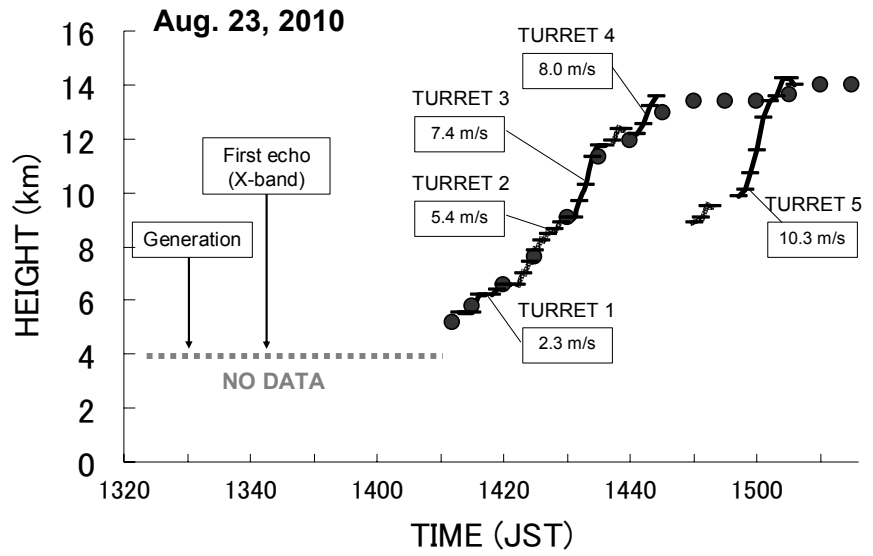

Fig. 7. Time sequences of the cloud height. Dots and bars denote the height of $\mathrm{Cb}$ and that of each turret, respectively.

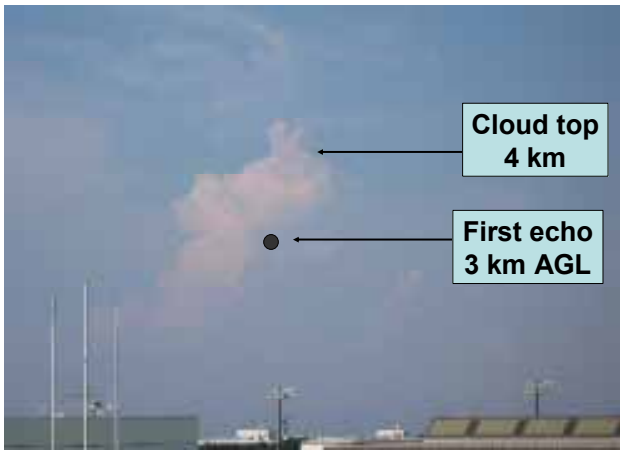

Fig. 8. A photo of a cumulonimbus on 24 July 2010 at 16:25 JST.
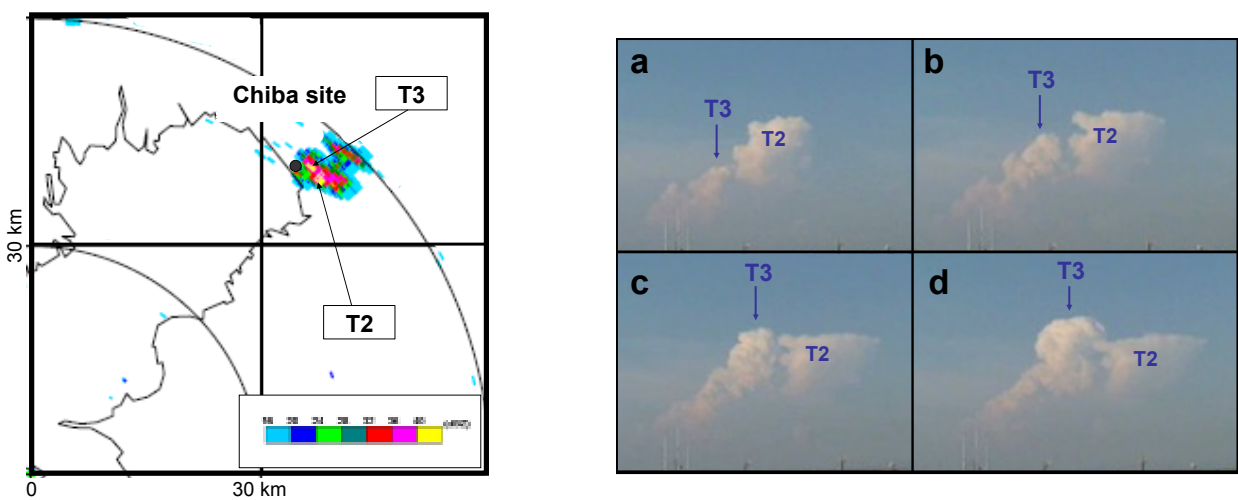

Fig. 9. X-band radar echo patterns of PPI $\left(\mathrm{EL}=2.4^{\circ}\right)$ on 24 July 2010 at $16: 51 \mathrm{JST}$ (left). Video still images of turret 3 on 24 July 2010 (right). (a) 16:50 JST. (b) 16:53. (c) 16:56. (d) 17:00. 
Figure 5 shows a time sequence of $\mathrm{Cb}$ images taken from the Yokosuka site from 14:12 to 15:12 JST when the Cb developed vertically. The Cb turret which exceeded a height of $5 \mathrm{~km}$ AGL was named as the number of the turret in this paper. Turret 1 (T1) developed vertically at 14:12 JST ((a) in Fig. 5), and reached a height of $7 \mathrm{~km}$ AGL at 14:14 JST. The height of the Turret 2 top was estimated to be $7 \mathrm{~km}$ AGL at 14:22 JST (b) and reached a height of $9 \mathrm{~km}$ AGL at 14:30 JST. Figure 6 shows the X-band echo intensity at 14:22 JST. There were some $\mathrm{Cb}$ echoes over the Boso Peninsula and the most developing cell was corresponded with Turret 2. Other echoes were corresponded with the Cb clouds occurred south side of Turret 2 as shown in Fig. 5 (b). Turrets 3 developed rapidly and reached $11 \mathrm{~km}$ AGL at 14:35 JST (c), corresponded to developing echo cell, which had strong echo intensities of more than $40 \mathrm{dBZ}$. The top of Turret 3 exceeded a height of $10 \mathrm{~km}$ at 14:38 JST. The maximum horizontal size of the echo was approximately $10 \mathrm{~km}$ of diameter at a height of $4 \mathrm{~km}$.

After 14:40 JST an anvil began to propagate as the symmetric diverging pattern (d). Turret 4 reached a height of $14 \mathrm{~km}$ AGL at 14:42 JST. As Turret 5 and several turrets continued to generate one after another, the anvil continued to propagate and the $\mathrm{Cb}$ cloud maintained its shape during 30 minutes (e). The $\mathrm{Cb}$ cloud began to dissipate at 15:10 JST, which corresponds to the time when Turret 5 was observed to be dissipating (f). Although other turrets were generated from 15:10 JST, those did not reach up to $5 \mathrm{~km}$ AGL. A lifetime of the $\mathrm{Cb}$ was approximately two hours. A short-range rain shower and thunder were observed below the $\mathrm{Cb}$, according to many eyewitness accounts of the $\mathrm{Cb}$ and rain shower. The overshooting phenomenon which was defined as the top of the turret exceeded the level of anvil (a height of tropopause) was observed at 14:58 JST (Fig.6).

Figure 7 denotes the time sequences of the cloud heights, which was estimated from video images of each $\mathrm{Cb}$ turret every 60 seconds. The height of each turret was estimated geometrically from cloud images observed from the Yokosuka site, assuming the height of anvil equal to that of the tropopause (14 km AGL). Turret 1 appeared after 14:10 JST and developed till a height of $6 \mathrm{~km}$ AGL at 14:20 JST. Turret 2 and Turret 3 appeared continuously at 14:20 and 14:30 JST, and reached a height of $9 \mathrm{~km}$ and $11 \mathrm{~km}$, respectively. Turret 4 reached the tropopause $(14 \mathrm{~km})$ at 14:42 JST. After the formation of anvil, some turrets continued to develop, the vertical motion of Turret 5 was most active. The vertical growth speeds were calculated to be $2.3 \mathrm{~m} / \mathrm{s}$ (Turret 1), $5.4 \mathrm{~m} / \mathrm{s}$ (Turret 2), $7.4 \mathrm{~m} / \mathrm{s}$ (Turret 3), $8.0 \mathrm{~m} / \mathrm{s}$ (Turret 4) and $10.3 \mathrm{~m} / \mathrm{s}$ (Turret 5), based on the temporal change of each turret as shown in Fig. 5. The peak height of the turret and the X-band echo top were $14 \mathrm{~km}$ AGL at 14:50 JST and $12 \mathrm{~km}$ AGL at 14:50 JST, respectively. A total of five turrets developed at the same location for approximately one hour (Fig. 5). Although each turret developed vertically, the head of Turret 4 and Turret 5 slightly inclined to the northeastward under the influence of upper $\mathrm{SW}$ wind up to $300 \mathrm{hPa}$ as shown in Fig. 3.

\subsection{Case II : Multi-turret on 24 July 2010}

Kobayashi et al. (2011) showed the developing process of an isolated $\mathrm{Cb}$ above the cloud radar site on 24 July 2010, using the 95-GHz cloud radar, the X-band radar, and photogrammetry in mid-summer day. A continuous generation of turrets was observed and a total of four turrets formed. Figure 8 shows a photograph taken from the Yokosuka site at 16:25 JST when the first echo was observed by the X-band radar. The Cb developed suddenly near the Chiba site after 16:00 JST. At 16:25 JST, the first echo appeared at a height of $3 \mathrm{~km}$, 
and the echo developed rapidly, having an echo core region of $30 \mathrm{dBZ}$ at 16:35 JST. The height of the cloud top was estimated to be $4 \mathrm{~km}$ AGL at 16:25 JST. Figure 9 shows the $\mathrm{X}$-band echo intensity at 16:51 JST when the peak of precipitation was observed at the Chiba site. Turrets 2 corresponded to a developing echo cell, which contained strong echo intensities of more than $30 \mathrm{dBZ}$, and occurred at 16:35 JST. The maximum horizontal size of the echo was approximately $10 \mathrm{~km}$ of diameter at a height of 3 to $4 \mathrm{~km}$. The top of the echo exceeded a height of $10 \mathrm{~km}$ at 16:45 JST. A short-range rain shower was observed at the Chiba site. Turret 3 generated close to Turret 2 at 16:48 JST (arrows in Fig. 9). Each turret corresponded well with the radar echo cells as shown in Fig. 9.

Figure 10 denotes the time sequences of the cloud heights. The height of each turret was estimated from video images of each $\mathrm{Cb}$ turret every 120 seconds. The height of each turret was estimated geometrically from cloud images taken at multiple locations using a stereo-photographing method. The distance between the two cameras was $14 \mathrm{~km}$ (Fig. 2). Turret 3, which had the largest value of vertical growth rate, appeared after the maximum height of Turret 2 (16:48 JST) and reached at a height of $11 \mathrm{~km}$ AGL at 16:58 JST. The vertical growth speeds were calculated to be approximately $10 \mathrm{~m} / \mathrm{s}$ (Turret 1), $8 \mathrm{~m} / \mathrm{s}$ (Turret 2), $13 \mathrm{~m} / \mathrm{s}$ (Turret 3) and $7 \mathrm{~m} / \mathrm{s}$ (Turret 4), based on the temporal change of each turret. The maximum height of the X-band echo was $10 \mathrm{~km}$ AGL at 16:50 JST.

A total of four turrets developed at the same location for approximately one hour. Each turret developed vertically, and subsequently, the head of the Cb moved eastward. As a result, the old turret propagated eastward and the new turret continued to be generated at the same place. No anvil was observed at the top of the turrets during the lifetime of the Cb because the inversion layer was existed around $11 \mathrm{~km}$ AGL (not shown).

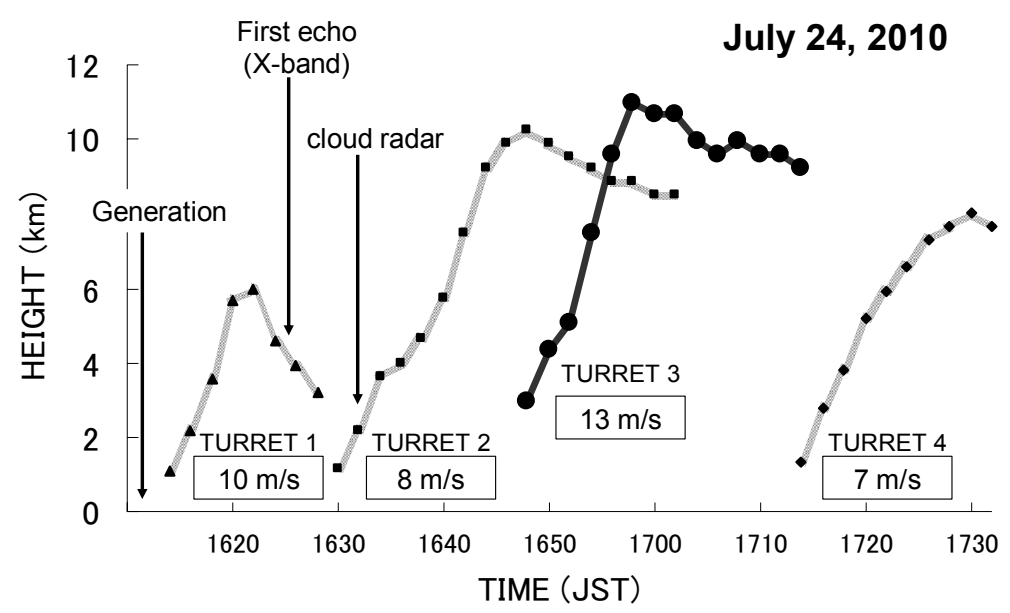

Fig. 10. Time sequences of each turret height in the case of 24 July 2010 (Reproduced of Fig. 5, Kobayashi et al. 2011). 


\subsection{Case III : Single turret on 7 August 2011}

It was wet in the Kanto region on 7 August 2011 under the advection of high temperature and moist air mass from the south. On the afternoon, many $\mathrm{Cu}$ and $\mathrm{Cb}$ generated over the Boso Peninsula and Kanagawa prefecture. Cb clouds developed after 14 JST and the intense radar echoes greater than $40 \mathrm{dBZ}$ were observed by the X-band radar. Figure 11 (a) denotes an example of $\mathrm{Cb}$ consisted by a single turret. The tower-shaped $\mathrm{Cb}$ generated at 12:20 JST on 7 August 2011 and the theodolite observation was started from 12:27 JST. The height of the turret was estimated by both the theodolite observation of the turret top (elevation angle) and the X-band radar observation of the first echo (horizontal distance). According to Fig.11 (b), the turret developed with the constant growth speed of $7 \mathrm{~m} / \mathrm{s}$. After the turret reached the maximum height (11 km AGL), the Cb disappeared at 12:40 JST.

In the present study, three cases of isolated Cbs, which developed vertically in the Kanto region in mid-summer days, were presented. The growth speeds of the Cb turrets were quite different during the $\mathrm{Cb}$ development in these cases. The growth speed increased gradually in the case of 23 August 2010. Although, the first echo appeared at 13:42 JST approximately 10 minutes after the generation of the $\mathrm{Cb}$, no distinct $\mathrm{Cb}$ turrets were generated during 40 minutes in the case. On the other hand, the turret appeared a few minutes after the generation of the $\mathrm{Cb}$ in the case of 24 July 2010. The generations of the $\mathrm{Cb}$ and the turret were simultaneously appeared in the case. It is not well known why no distinct turrets formed during 40 minutes in the case of 23 August.

These results suggest the manifold aspects of the $\mathrm{Cb}$ turret development. The relationship between the lifetime and the evolution of $\mathrm{Cb}$ turrets would be the important factor for the development of $\mathrm{Cb}$. In contrast to the behavior of convection initiation along the dry line observed in the USA (e.g., Weckwerth and Parsons 2006, Arnott et al. 2006), no remarkable changes of the isolated $\mathrm{Cb}$ and turrets were discussed. The behavior and evolution of smaller turrets are important for understanding the development of $\mathrm{Cb}$. Further studies are needed to observe the spatial distribution of the $\mathrm{Cb}$ echo pattern and the Doppler velocity fields in the $\mathrm{Cb}$ detected by the cloud radar and make clear the relationship between $\mathrm{Cb}$ turrets and the cloud radar echo patterns.
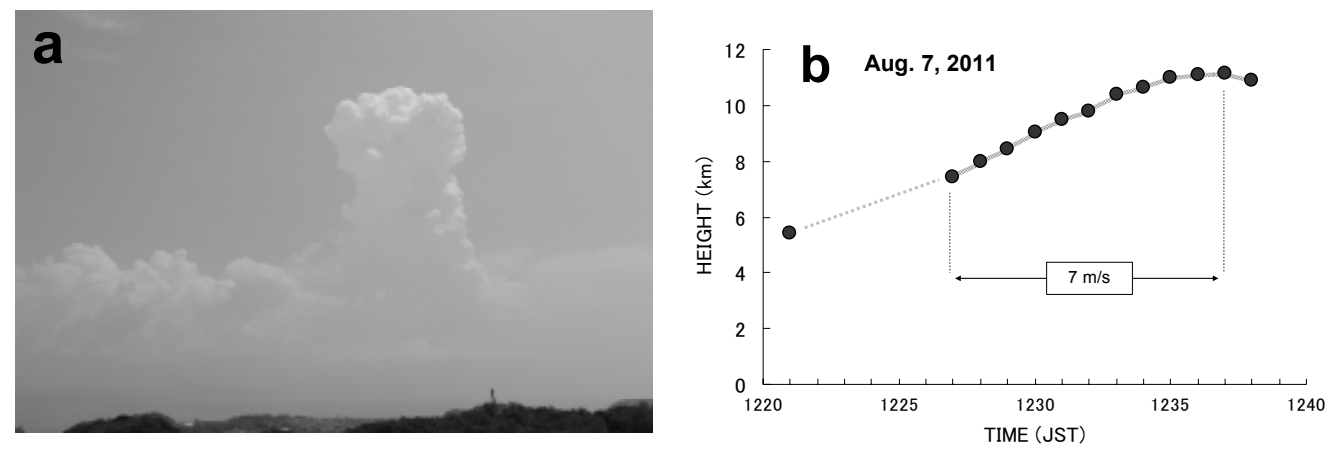

Fig. 11. (a) A photo of a cumulonimbus at 12:29 JST on 7 August 2011. (b) Time sequence of the turret height. 


\section{Conclusions}

On the basis of simultaneous observations of cumulonimbi using the 95-GHz FM-CW cloud radar FALCON-I, the X-band radar, and photogrammetry, several cases of cumulonimbus initiations in the Kanto region of Japan, were presented. The generation of the cumulonimbus was initiated by cloud turrets. A continuous generation of turrets was observed from the visible images, and the growth speeds of turrets were quite different among the life cycle of the cumulonimbus in these cases. Conclusions of this study are as follows:

(1) The cumulonimbus was organized by the continuous generation of turrets. At least distinct five turrets in the case on 23 August 2010 and four turrets in the case on 24 July 2010 were observed.

(2) The growth speeds of turrets were quite different among the life cycle of the cumulonimbus. The values of the growth rates increased gradually in these cases and varied from $2 \mathrm{~m} / \mathrm{s}$ to $13 \mathrm{~m} / \mathrm{s}$.

(3) The time relationship between the generation of cumulonimbus clouds and the vertical growth of turrets to the cloud top is different among the three cases. No distinct cumulonimbus turrets were generated during forty minutes from the generation of the cumulonimbus in the case of 23 August 2010.

Generally, a turret is organized by many tufts and cumulonimbus is organized by several turrets. The development of cumulonimbus may be influenced by the activity of each tuft or turret. The multi-scale structure of cumulonimbus, turrets and tufts would be a key concept for understanding the cumulus convections.

\section{Acknowledgments}

The authors would like to thank the Japan Meteorological Agency (JMA) for providing the meteorological data. We also wish to thank Mr. T. Kurino (JMA) and the University of Wyoming for providing the MTSAT-1R rapid scan data and the P-T chart as shown in Fig. 3. We also express thanks to anonymous reviewers for their valuable comments. This study was partly supported by a Grant-in-Aid for Scientific Research (C) 23510232.

\section{References}

Arnott, N. E., Y. P. Richardson, J. M. Wurman, and E. M. Rasmussen, 2006: Relationship between a weakening cold front, misocyclones, and cloud development on 10 June 2002 during IHOP. Mon. Wea. Rev., 134, 311-335.

Changnon, S., 1981: METROMEX: a review and summary. Meteor. Monographs, 18, AMS, Boston, MA, 181pp.

Fujibe, F., 1998: Spatial anomalies and long-term changes of precipitation in Tokyo. Tenki, 45, 7-18.

Fujibe, F., K. Sakagami, K. Chubachi and K. Yamashita, 2002: Surface wind patterns 
proceeding short-time heavy rainfall in Tokyo in the afternoon of midsummer days. Tenki, 49, 395-405.

Inoue, T. and F. Kimura, 2004: Urban effects on low-level clouds around the Tokyo metropolitan area on clear summer days. Geophys. Res. Lett., 31, L05103, doi : 10.1029/2003 GL018908.

Kobayashi, F., 2009: First radar echo generation in Tokyo metropolitan area during mid-summer days. Proceedings of 7 th International Conference on Urban Climate, 3.

Kobayashi, F. and N. Inatomi, 2003: First radar echo formation of summer thunderclouds in southern Kanto, Japan. J. Atmos. Electr., 23, 9-19.

Kobayashi, F., H. Sugawara, Y. Ogawa, M. Kanda and K. Ishii, 2007: Cumulonimbus generation in Tokyo metropolitan area during mid-summer days. J. Atmos. Electr., 27, 41-52.

Kobayashi, F., T. Takano and T. Takamura, 2011: Isolated cumulonimbus initiation observed by $95-\mathrm{GHz}$ FM-CW radar, X-band radar, and photogrammetry in the Kanto region, Japan. SOLA, 7, 125-128.

Kobayashi, F., Y. Ueno, N. Inatomi and T. Shimura, 2001: Cumulonimbus which brought heavy rain in the metropolitan area on 21 July 1999. Tenki, 48, 3-4.

Saito, T. and F. Kimura, 1998: Diurnal variation of convective precipitation in Chubu-Kanto area in the summer. Tenki, 45, 643-648.

Sato, N. and M. Takahashi, 1999: The interdiurnal variation of summer cumulus convection over the Kanto Plain in Japan. J. Meteor. Soc. Japan, 77, 1199-1220.

Seko, H., Y. Shoji and F. Fujibe, 2007: Evolution and airflow structure of a Kanto thunderstorm on 21 July 1999 (the Nerima heavy rainfall event). J. Meteor. Soc. Japan, 85, 455-477.

Takano, T., J. Yamaguchi, H. Abe, K. Futaba, S. Yokote, Y. Kawamura, T. Takamura, H. Kumagai, Y. Ohno, Y. Nakanishi and T. Nakajima, 2008: Development and performance of the millimeter-wave cloud profiling radar at $95 \mathrm{GHz}$ - sensitivity and spatial resolution -. IEEJ Trans. FM, 128, 257-262.

Weckwerth, T. M., and D. B. Parsons, 2006: A review of convection initiation and motivation for IHOP_2002. Mon. Wea. Rev., 134, 5-22.

(Received November 16, 2011; revised November 27, 2011; accepted December 1, 2011) 